\title{
Flavobacterium multivorum, a New Species Isolated from Human Clinical Specimens and Previously Known as Group IIk, Biotype 2
}

\author{
B. HOLMES, ${ }^{1}$ R. J. OWEN, ${ }^{1}$ AND R. E. WEAVER ${ }^{2}$ \\ National Collection of Type Cultures, Central Public Health Laboratory, London NW9 5HT, United \\ Kingdom, ${ }^{1}$ and Centers for Disease Control, Atlanta, Georgia $30333^{2}$
}

\begin{abstract}
Thirty-two gram-negative bacterial strains, most of which were yellow-pigmented and isolated from clinical sources, were compared with 17 culture collection strains representing 13 named strains of four Flavobacterium species and 4 unnamed strains of Flavobacterium species. Twenty-nine of the strains were originally received as or subsequently assigned to group IIk, biotype 2 . All 49 strains were examined for 127 characteristics, including reactions to 58 enzyme tests (API ZYM system), and the data were analyzed by numerical taxonomic methods involving estimation of Gower's general similarity coefficient and clustering by unweighted pair-group average linkage and single-linkage analyses. Twenty-eight of the group IIk, biotype 2, strains formed a single, well-defined cluster $(92.0 \%$ similarity level). These 28 strains were aerobic, gram-negative, nonmotile, oxidative rods; the mean base composition of the deoxyribonucleic acids of 11 strains was $39.6 \pm 0.5 \mathrm{~mol} \%$ guanine plus cytosine. Distinctive features of the 28 strains were the ability to produce acid from a range of carbohydrates and their resistance to antimicrobial agents. The 28 strains were classified in the genus Flavobacterium, but they could not be assigned to any previously defined species. Therefore a new species, with the name Flavobacterium multivorum, is proposed for these 28 strains; the type strain is B5533 (= NCTC 11343).
\end{abstract}

Tatum et al. (25) described 140 strains of gram-negative, yellow-pigmented, rod-shaped bacteria thought to resemble Pseudomonas or possibly Xanthomonas species isolated from human and other sources of clinical interest. These bacteria were referred to as "group IIk," and two biotypes were recognized (although the word "biovar" is now recommended in place of "biotype" [16], we continue to use "biotype" here because of its historical association with group IIk). The 100 strains of biotype 1 were deeply yellow pigmented, whereas the 40 strains of biotype 2 were usually pale to light yellow. The motility observations of the group IIk strains in semisolid agar medium were sometimes equivocal; hence, wet-mount preparations were recommended. Five percent of the biotype 2 strains were reported as motile, and for both biotypes of group IIk, strains were described as monotrichous (25).

Holmes et al. (10) studied various yellow-pigmented isolates originally received at the $\mathrm{Na}$ tional Collection of Type Cultures (NCTC), London, United Kingdom, for identification and showed, by numerical analysis of phenotypic characteristics, that 27 strains formed a cluster with two reference strains of group IIk, biotype 1. The name Pseudomonas paucimobilis was proposed by Holmes et al. (10) for these 29 strains because most motile strains contained few actively motile cells. Motile strains had a single polar flagellum. Holmes et al. excluded two reference strains of group IIk, biotype 2, and two biochemically similar strains from the $P$. paucimobilis cluster. Deoxyribonucleic acid (DNA) base compositions (moles percent guanine plus cytosine [G+C] provided clear evidence that biotypes 1 and 2 were unrelated: the biotype 2 strains had $\mathrm{G}+\mathrm{C}$ contents of 39.6 $\mathrm{mol} \%$, whereas those of $P$. paucimobilis (biotype 1) were notably higher (ca. $65.0 \mathrm{~mol} \%$ ). The biotype 2 strains were also resistant to a wider range of antibiotics than were the biotype 1 strains. The lack of motility and the $\mathrm{G}+\mathrm{C}$ contents of $39 \%$ of the group IIk, biotype 2, strains was confirmed by E. Yabuuchi, I. Yano, E. Tanimura, and A. Ohyama [Abstr. Annu. Meet. Am. Soc. Microbiol. 1979, C(H)32, p. 351], who believed, on the basis of these characteristics as well as of 90 phenotypic tests and cellular lipid analyses, that biotype 2 should not be regarded as Pseudomonas-like but should be placed in a "new" genus. Dees et al. (3) reported that group IIk, biotype 2, was readily distinguishable from $P$. paucimobilis by cellular fatty acids and suggested that it might be an additional species of Flavobacterium.

In the present study, a numerical analysis of 
phenotypic characteristics, determinations of DNA base compositions, and determinations of susceptibilities to antimicrobial agents were used to investigate the taxonomic relationships between group IIk, biotype 2 , strains and species of the genus Flavobacterium as redefined by Holmes and Owen (9). Evidence is presented that 28 of 29 strains originally assigned at the Centers for Disease Control (Atlanta, Ga.), NCTC, or Madigan Army Medical Center (Tacoma, Wash.) to group IIk, biotype 2, constitute Flavobacterium multivorum, a new species.

\section{MATERIALS AND METHODS}

Bacterial strains. The 49 bacterial strains studied (Table 1) comprised: 28 strains of $F$. multivorum, 4 unnamed strains resembling $F$. multivorum, and 17 culture collection strains representing named and unnamed Flavobacterium species.

Bacteriological investigations. The strains were maintained on nutrient agar $(25 \mathrm{~g}$ of Oxoid nutrient broth powder CM 67 [Oxoid Ltd., Basingstoke, United Kingdom], and $12 \mathrm{~g}$ of New Zealand agar per liter of distilled water) under aerobic conditions and were tested at their optimum growth temperatures, usually $30^{\circ} \mathrm{C}$. Colonial morphology was described from aerobic growth on nutrient agar, and hemolysis was determined from aerobic growth on $5 \%$ (vol/vol) horse blood agar. Pigmentation was recorded from growth on nutrient and tyrosine agars, and fluorescence was tested for on medium B of King et al. (15). The Gram reaction was determined by Lillie's modification as described by Cowan (2). Motility was tested by the hanging-drop method on overnight cultures grown at room temperature $\left(18\right.$ to $22^{\circ} \mathrm{C}$ ) and at $37^{\circ} \mathrm{C}$ in nutrient broth (Oxoid CM 67).

The biochemical characteristics investigated are listed in Tables 2 through 4 , and the methods used have been described by Holmes et al. (8), but the following changes or additions were made. Indole production was tested with Kovács reagent and with Ehrlich reagent, the latter by method 3 of Cowan (2). Tributyrin hydrolysis was tested for on nutrient agar containing $1 \%$ (vol/vol) glycerol tributyrate, as described by Hayes (6). Phosphatase production was determined by method 1 of Cowan (2). Tests for the production of 58 specific enzymes (listed in Tables 2 through 4) were performed with a commercially produced kit system (API System, La Balme-les-Grottes, Montalieu-Vercieu, France). The structure of the API ZYM gallery, the choice of substrates, how the enzymes are detected, and the various applications of the system are fully described elsewhere (D. Monget, $\mathrm{Ph} . \mathrm{D}$. thesis, Université Claude Bernard, Lyons, France, 1978). Nineteen of the enzyme tests that constitute the standard API ZYM gallery are widely available. The remaining 39 enzyme tests constitute four experimental API galleries: ZYM II, AP 1, AP 2, and AP 3. A standardized procedure was adopted to ensure that results of the enzyme tests were comparable between strains. Each strain was grown overnight on a nutrient agar slant (in 6- by $5 / 8$-in. [ca. 15.2 by 1.6 $\mathrm{cm}$ ] test tubes) at $30^{\circ} \mathrm{C}$. The bacteria were washed off the slant and suspended in $6 \mathrm{ml}$ of distilled water (API System 2011) in a 5 by $1 / 2$-in. (ca. $12.7-$ by $1.2-\mathrm{cm}$ ) test tube. The absorbance, at $550 \mathrm{~nm}$, of the resulting bacterial suspension was measured in a Pye Unicam model SP 600 spectrophotometer to check that it was in the range 1.0 to 2.0 . Suspensions with an absorbance outside this range were not used because of possible weak color reactions. An absorbance of just over 1.0 was considered by the manufacturer to be most suitable. Two drops of the suspension was inoculated into each cupule of the test galleries, which were incubated at $30^{\circ} \mathrm{C}$ for $4 \mathrm{~h}$. Reagents were then added to each cupule according to the manufacturer's instructions. Positive results in 56 enzyme tests were denoted by a color change. In two additional tests in the ZYM II gallery, positive results were detected by fluorescence under an ultraviolet light source. After reading the results of tests 2 through 10 in the ZYM II gallery, test 1 in that gallery and all the tests in the other four galleries were exposed to a $1,000-\mathrm{W}$ light source. The results were graded 0 through 5 according to the intensity of color change and based on the interpretation scheme provided by the manufacturer. A positive result in the present paper included all grades of color change in the range 3 to 5 , as recommended by the manufacturer.

Susceptibilities to antimicrobial agents were tested in selected strains by an agar dilution method. Twofold dilutions of antimicrobial agents were added to Diagnostic Sensitivity Test agar (Oxoid CM 261) to give a range of concentrations of 128 to $0.006 \mu \mathrm{g} / \mathrm{ml}$. Lysed horse blood $(2 \%, \mathrm{vol} / \mathrm{vol})$ was added to medium containing sulfonamide or co-trimoxazole. The medium was dispensed into petri dishes, which were inoculated, using a replicating device, with $0.003-\mathrm{ml}$ volumes of overnight broth cultures of strains diluted to contain about $10^{5}$ cells per ml. Each plate was also inoculated with three control strains of known susceptibilities: Escherichia coli NCTC 10418, Pseudomonas aeruginosa NCTC 10662, and Staphylococcus aureus NCTC 6571. The minimum inhibitory concentration of an antimicrobial agent for each strain was defined as the lowest concentration completely inhibiting growth after overnight incubation at $30^{\circ} \mathrm{C}$.

Computation of data. A total of 127 characteristics (listed in Tables 2 through 4) were used in the numerical analysis. The majority of tests were treated as two-state characters (all-or-none characters, such as present or absent, which may be symbolized by + and -$)$, and the results were coded as $1(+)$ or $0(-)$ (moderately positive results, recorded as \pm , were treated as +; weakly positive results, recorded as $\mp$, were treated as -). For two-state related tests, implied negative results were coded as no comparison (24). The Hugh and Leifson oxidation-fermentation test was treated as a qualitative multistate character (states cannot be ordered; in a series, such as A, B, C, one can only say that any two are the same or different; there is no implication that the difference between $A$ and B is greater or less than that between A and C, for example). The test results for gelatin hydrolysis (the stab and plate methods) were combined to give a single quantitative multistate character (has states that may be ordered in magnitude: 0 , both methods negative; 1 , plate only positive; 2 , both methods posi- 
TABLE 1. Strains used in this study

\begin{tabular}{|c|c|c|c|}
\hline \multirow{2}{*}{ Strain no. ${ }^{a}$} & \multirow{2}{*}{$\begin{array}{l}\text { Received as (name or other } \\
\text { designation): }\end{array}$} & \multicolumn{2}{|c|}{ Source of isolation } \\
\hline & & Anatomic & Geographic $^{b}$ \\
\hline \multicolumn{4}{|l|}{ Strains assigned to $F$. multivorum: } \\
\hline CL201/75 & Unidentified & Human clinical & United Kingdom \\
\hline $\mathrm{CL} 23 / 79^{\mathrm{c}}$ & Group IIk, biotype 2 & Lung (autopsy) & Washington \\
\hline CL24/79 & Group IIk, biotype 2 & Eye & Washington \\
\hline $\mathrm{CL} 25 / 79^{c}$ & Group IIk, biotype 2 & Serum & Washington \\
\hline $\mathrm{CL} 26 / 79^{c}$ & Group IIk, biotype 2 & Throat & Washington \\
\hline CL406/79 & Unidentified & Peritoneal fluid & Illinois \\
\hline 8354 & Group IIk, biotype 2 & Blood & Oregon \\
\hline A561 & Group IIk, biotype 2 & Abdominal fluid & New York \\
\hline A1327 & Group IIk, biotype 2 & Blood & Connecticut \\
\hline A7317 & Group IIk, biotype 2 & Urine & Wisconsin \\
\hline A7371 & Group IIk, biotype 2 & Blood & New York \\
\hline A7543 & Group IIk, biotype 2 & Throat & Missouri \\
\hline A7810 & Group IIk, biotype 2 & Skin & Texas \\
\hline A8895 $(=$ NCTC 11033$)$ & Group IIk, biotype 2 & Serous cavity fluid & Georgia \\
\hline B2623 & Group IIk, biotype 2 & Blood & Washington \\
\hline B3159 (= NCTC 11034) & Group IIl, biotype 2 & Blood & New Jersey \\
\hline B3392 & Group IIk, biotype 2 & Blood & Illinois \\
\hline B5147 & Group IIk, biotype 2 & Urine & Texas \\
\hline B5367 & Group IIk, biotype 2 & Cerebrospinal fluid & Egypt \\
\hline B5533 $(=$ NCTC 11343) & Group IIk, biotype 2 & Spleen & Washington \\
\hline B5759 & Group IIk, biotype 2 & Abdominal hematoma & Zaire \\
\hline B9042 & Group IIk, biotype 2 & $\begin{array}{l}\text { Catheter tip, kidney } \\
\text { transplant }\end{array}$ & Texas \\
\hline D3833 & Group IIk, biotype 2 & Wound & Georgia (probably) \\
\hline D8510 & Group IIk, biotype 2 & Blood & New York \\
\hline D8864 & Group IIlk, biotype 2 & Urine & Washington \\
\hline E2786 & Group IIk, biotype 2 & Eye discharge & Pennsylvania \\
\hline E3089 & Group IIk, biotype 2 & Cerebrospinal fluid & Missouri \\
\hline E3540 & Group IIk, biotype 2 & Blood & Pennsylvania \\
\hline \multicolumn{4}{|l|}{$\begin{array}{l}\text { Unnamed strains resembling } F \text {. } \\
\text { multivorum: }\end{array}$} \\
\hline CL404/79 & Unidentified & Blood & United Kingdom \\
\hline A14/65 & Unidentified & Wound swab & United Kingdom \\
\hline E894 & Unidentified & Unknown & United Kingdom \\
\hline 8291 & Group IIk, biotype 2 & Blood & Louisiana \\
\hline CIP 12.75 & Flavobacterium sp. & Unknown & Unknown \\
\hline \multicolumn{4}{|l|}{ Reference strains: } \\
\hline La $724\left(=\right.$ NCTC 11212) ${ }^{e}$ & F. balustinum & Heart blood of fish & France \\
\hline CL88/76 ( = NCTC 11099) & " $F$. breve" & Bronchial secretion & Switzerland \\
\hline CL626/75 (= NCTC 11162) & "F. breve" & Eye swab & Eire \\
\hline CL669/76 (= NCTC 11163) & "F. breve" & Urine & Czechoslovakia \\
\hline ATCC $13253(=\text { NCTC } 10016)^{e}$ & F. meningosepticum & Spinal fluid & Massachusetts \\
\hline ATCC $13254(=$ NCTC 10585) & F. meningosepticum & Blood & Florida \\
\hline ATCC $13255(=$ NCTC 10586) & F. meningosepticum & Spinal fluid and throat & South Carolina \\
\hline 6925 (= NCTC 10587) & F. meningosepticum & Cerebrospinal fluid & Sri Lanka \\
\hline 8388 (= NCTC 10588) & F. meningosepticum & Blood & New York \\
\hline $8707(=$ NCTC 10589$)$ & F. meningosepticum & Spinal fluid & New York \\
\hline ATCC $4651(=\text { NCTC } 11036)^{e}$ & F. odoratum & Unknown & Unknown \\
\hline ATCC 29979 (= NCTC 11179) & F. odoratum & Urine & United Kingdom \\
\hline CL $229 / 67$ (= NCTC 11180) & F. odoratum & Wound swab & United Kingdom \\
\hline 3531 (= NCTC 10795) & $\begin{array}{l}\text { Flavobacterium sp. group } \\
\text { IIb }\end{array}$ & Sputum & South Carolina \\
\hline $3716(=$ NCTC 10796$)$ & $\begin{array}{l}\text { Flavobacterium sp. group } \\
\text { IIb }\end{array}$ & Trachea at autopsy & Unknown \\
\hline B1858 (= NCTC 10797) & $\begin{array}{l}\text { Flavobacterium sp. group } \\
\text { IIb }\end{array}$ & Drinking fountain spout & Arkansas \\
\hline
\end{tabular}

${ }^{a}$ Key to sources: NCTC, National Collection of Type Cultures, Central Public Health Laboratory, London, United Kingdom; ATCC, American Type Culture Collection, Rockville, Md.; CIP, Collection de l'Institut Pasteur, Paris, France; La, International Center for Information on and Distribution of Type-Cultures, Lausanne, Switzerland; strains A14/65 and E894 and those prefixed by CL are strains referred for identification to the NCTC Computer Identification Laboratory; all other strains with three- or four-digit numbers and with or without a single-letter prefix are strains referred for identification to the Special Bacteriology Section, Centers for Disease Control, Atlanta, Ga.

${ }^{b}$ Country, or state in the United States.

' Strain obtained from Madigan Army Medical Center, Tacoma, Wash., and presumed to have been isolated in Washington.

${ }^{d}$ A case report on this strain has been published (4).

Type strain. 
TABLE 2. Characteristics for which all 28 strains of $F$. multivorum are positive

\begin{tabular}{ll}
\hline $\begin{array}{l}\text { Acid from the following carbohydrates (tested in an } \\
\text { ammonium salt medium): }\end{array}$ & $\begin{array}{l}\text { N-Acetyl- } \beta \text {-D-glucosaminidase } \\
\text { G-D-Cellobiosidase }\end{array}$ \\
Glucose & L-Phenylalanyl-2-naphthylamide hydrolase \\
Arabinose & L-Lysyl-2-naphthylamide hydrolase \\
Cellobiose & L-Histidyl-2-naphthylamide hydrolase \\
Fructose & Glycyl-2-naphthylamide hydrolase \\
Lactose & $\alpha$-L-Aspartyl-2-naphthylamide hydrolase \\
Maltose & L-Arginyl-2-naphthylamide hydrolase \\
Raffinose & L-Alanyl-2-naphthylamide hydrolase \\
Salicin & S-Benzyl-L-cysteyl-2-naphthylamide hydrolase \\
Sucrose & L-Methionyl-2-naphthylamide hydrolase \\
Trehalose & L-Glycyl-glycyl-2-naphthylamide hydrolase \\
Xylose & Glycyl-L-phenylalanyl-2-naphthylamide hydrolase \\
Catalase production & Glycyl-L-prolyl-2-naphthylamide hydrolase \\
Cytochrome $c$ oxidase production & L-Leucyl-glycyl-2-naphthylamide hydrolase \\
Esculin hydrolysis & L-Seryl-tyrosyl-2-naphthylamide hydrolase \\
Growth at $37^{\circ} \mathrm{C}$ & L-Glutaminyl-2-naphthylamide hydrolase \\
Growth at room temperature ${ }^{a}$ & $\alpha$-L-Glutamyl-2-naphthylamide hydrolase \\
Growth on MacConkey agar & L-Ornithyl-2-naphthylamide hydrolase \\
Oxidative in Hugh and Leifson oxidation-fermentation & L-Seryl-2-naphthylamide hydrolase \\
test & L-Tryptophyl-2-naphthylamide hydrolase \\
Phosphatase production & N-Carbobenzoxy-glycyl-glycyl-L-arginyl-2-naph- \\
Production of the following enzymes: ${ }^{b}$ & thylamide hydrolase \\
Alkaline phosphatase &
\end{tabular}

\footnotetext{
${ }^{a}$ Room temperature $=18$ to $22^{\circ} \mathrm{C}$.

${ }^{b}$ Tested by using various API ZYM galleries.

${ }^{c}$ Enzyme test included in the standard API ZYM gallery.
}

tive). A similar procedure was adopted for the test results for $\mathrm{H}_{2} \mathrm{~S}$ production (the lead acetate paper and triple sugar iron agar methods). Test results for indole production (as determined with Ehrlich reagent) and for the API ZYM tests were also treated as quantitative multistate characters; for indole production, test results were coded as $3(+), 2( \pm), 1(\mp)$, or $0(-)$; for the ZYM tests, the color grade (0 to 5 ) was used as the result code (e.g., color grade 4 was coded as 4 ). The between-strain similarities were calculated by using Gower's (5) general similarity coefficient $\left(S_{G}\right.$ in the notation of Sneath and Sokal [24]), and negative matches were included for the two-state characters. The strains were clustered by the method of unweighted pair-group average linkage (24) and by single-linkage cluster analysis (24). All calculations were carried out on the ICL 1900 computer at Nottingham University (Nottingham, United Kingdom) with a program developed by M. J. Sackin of the Department of Microbiology, University of Leicester (Leicester, United Kingdom). The median organism of the new taxon was determined (17), and the within- and between-taxon average similarities were calculated as arithmetic means of the relevant similarities.

DNA isolation. Cultures were grown overnight at $30^{\circ} \mathrm{C}$ in nutrient broth with aeration at $200 \mathrm{rpm}$ in an orbital incubator (Gallenkamp Ltd., London, United Kingdom). The bacterial cells were collected by centrifugation and were suspended in $0.15 \mathrm{M} \mathrm{NaCl}-0.10$ $\mathrm{M}$ ethylenediaminetetraacetic acid at $\mathrm{pH}$ 8.0. Pronase
(Koch-Light Laboratories Ltd., Colnbrook, United Kingdom) was added to a final concentration of 200 $\mu \mathrm{g} / \mathrm{ml}$, and the bacteria were lysed with $2 \%$ (wt/vol) sodium lauryl sulfate at $60^{\circ} \mathrm{C}$ for $15 \mathrm{~min}$. The lysate was incubated overnight at $37^{\circ} \mathrm{C}$ and then mixed thoroughly with $1 \mathrm{M}$ sodium perchlorate and deproteinized with an equal volume of a 50:50 (vol $/ \mathrm{vol})$ mixture of phenol and chloroform. Purification of the DNA was completed essentially by the method of Marmur (18), but it was supplemented by treatment twice with 50 $\mu \mathrm{g}$ of ribonuclease (bovine pancreas; BDH Chemicals Ltd., Poole, United Kingdom) per $\mathrm{ml}$ and final precipitation with 2-ethoxyethanol.

DNA base composition. The DNA base composition, expressed as moles percent $\mathrm{G}+\mathrm{C}$ to total bases, was estimated from the thermal denaturation temperature, which was determined by the method of Marmur and Doty (19). Thermal denaturation of DNA was carried out in a Pye Unicam SP 1800 spectrophotometer equipped with an SP 876 series 2 temperature program controller and heated cell block. The absorbance changes at $260 \mathrm{~nm}$ were recorded on a Pye Unicam AR 25 linear recorder. The temperature of the DNA solution was measured in the cuvette with a thermistor thermometer (7). The $\mathrm{G}+\mathrm{C}$ content was calculated from the thermal denaturation temperature determined in $0.05 \mathrm{M} \mathrm{NaCl}$ buffered with $0.005 \mathrm{M}$ trisodium citrate $(1 / 3 \mathrm{SSC})$ at $\mathrm{pH} 7.0$ by the equation moles percent $\mathrm{G}+\mathrm{C}=52.0+2.24$ (thermal denaturation temperature - 84.4); this was derived using the 
TABLE 3. Characteristics for which all 28 strains of $F$. multivorum are negative

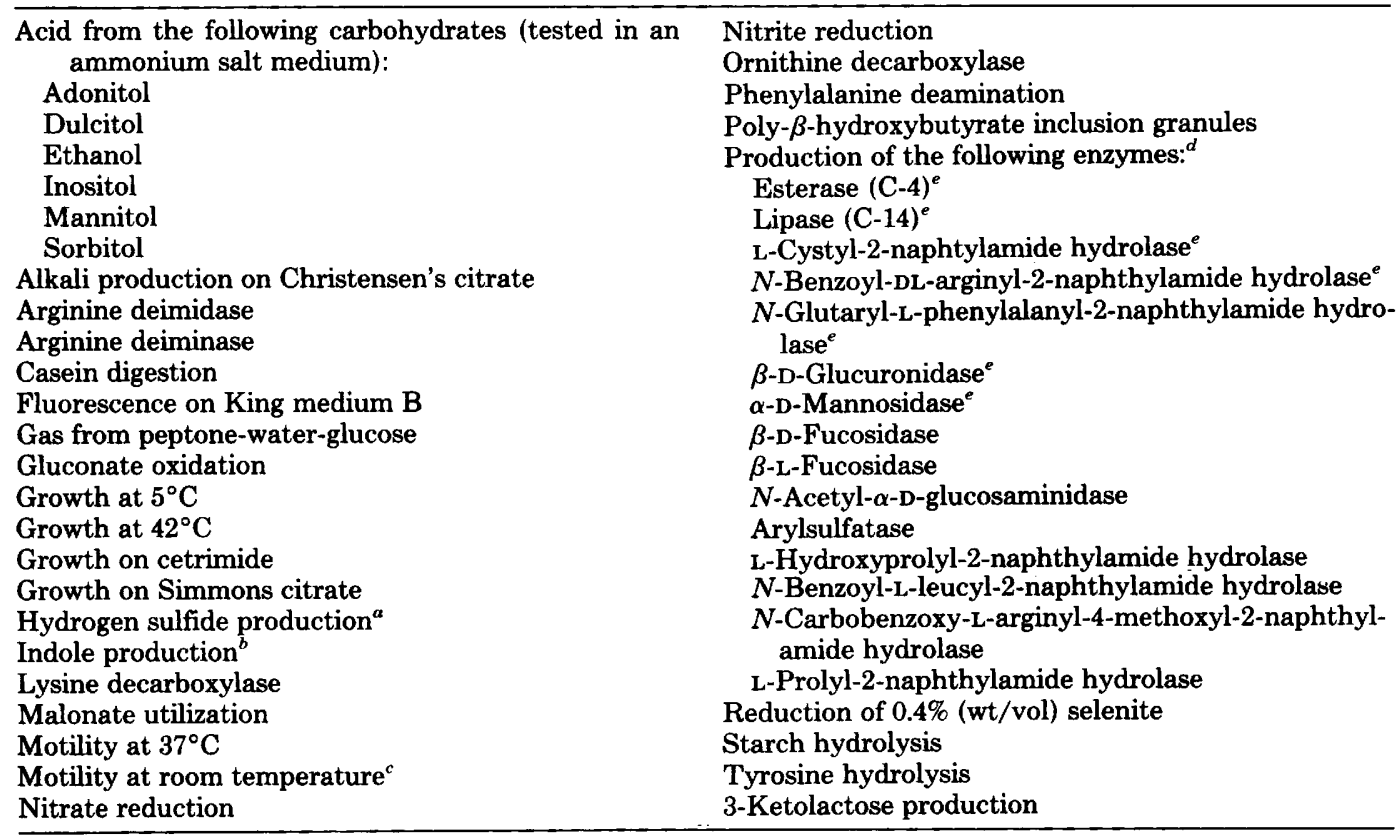

${ }^{a}$ By both lead acetate paper and triple sugar iron agar methods.

$b$ Tested with Kovács and Ehrlich reagents.

${ }^{c}$ Room temperature $=18$ to $22^{\circ} \mathrm{C}$.

${ }^{d}$ Tested by using various API ZYM galleries.

${ }^{e}$ Enzyme test included in the standard API ZYM gallery.

general equation of Owen et al. (20), and it expressed the $\mathrm{G}+\mathrm{C}$ content relative to reference DNA from $E$. coli B NCTC $10537(52.0 \mathrm{~mol} \% \mathrm{G}+\mathrm{C})$.

\section{RESULTS}

Numerical taxonomic analysis. The similarities between the strains studied are illustrated in a dendrogram (Fig. 1) derived by singlelinkage cluster analysis. The strains of $F$. multivorum, which comprised 28 of 29 strains originally assigned at the Centers for Disease Control, NCTC, or Madigan Army Medical Center to group IIk, biotype 2, formed a homogeneous cluster at the $92.0 \%$ similarity level, and the majority of strains $(26 / 28)$ joined within the cluster at a similarity level of $93.5 \%$. Table 5 lists the average within- and between-taxon similarities of $F$. multivorum, of the five strains phenotypically similar to $F$. multivorum, and of the clusters formed by the various reference strains at the $92.0 \%$ similarity level. The average withintaxon similarity of $91.2 \%$ for $F$. multivorum was just slightly lower than the range of values determined for "Flavobacterium breve" and $F$. odoratum (Table 5) and was higher than the range of values determined for $F$. meningosepticum and Flavobacterium sp. group IIb. The latter two taxa were phenotypically heterogeneous and failed to form discrete clusters at or above the $92.0 \%$ similarity level (Fig. 1). In the $F$. multivorum cluster, strain B5533 was the centrostrain but was not the median organism because it produced acid from rhamnose in ammonium salt-sugar medium. Strains CL201/75, CL23/79, B3159, D8510, and E3540 were the least typical members of $F$. multivorum, and each differed from others of the cluster in two, but not the same two, biochemical characteristics (see Table 4). The numerical analysis demonstrated that $F$. multivorum was quite distinct from the other recognized Flavobacterium species: $F$. balustinum, " $F$. breve," $F$. meningosepticum, F. odoratum (9), and Flavobacterium sp. group IIb. The name " $F$. breve" is in quotation marks because it is not on the Approved Lists of Bacterial Names (23). However, a proposal has been made to effect revival of " $F$. breve" with NCTC 11099 as the type strain (Holmes and Owen, submitted for publication).

Characteristics of $\boldsymbol{F}$. multivorum. The 28 of 29 strains originally assigned at the Centers for Disease Control, NCTC, or Madigan Army Medical Center to group IIk, biotype 2, were strictly aerobic, gram-negative, uniformly 
TABLE 4. Characteristics for which the 28 strains of $F$. multivorum give different results

\begin{tabular}{|c|c|c|c|}
\hline Characteristic & $\begin{array}{l}\text { No. of strains } \\
\text { positive }\end{array}$ & $\begin{array}{l}\text { Result for type } \\
\text { strain (B5533) }\end{array}$ & Strain(s) that gave the less common result \\
\hline Acid from ammonium salt-glycerol & 27 & + & $\mathrm{B5367}$ \\
\hline Acid from $10 \%(\mathrm{wt} / \mathrm{vol})$ glucose & 27 & + & CL201/75 \\
\hline Acid from $10 \%$ (wt/vol) lactose & 27 & + & CL201/75 \\
\hline Growth on $\beta$-hydroxybutyrate & 27 & + & A7810 \\
\hline Tween 80 hydrolysis & 27 & + & D8510 \\
\hline Urease production & 27 & + & E3540 \\
\hline$\alpha$-D-Glucosidase production ${ }^{a, b}$ & 27 & + & CL23/79 \\
\hline Esterase-lipase (C-8) production ${ }^{a, b}$ & 25 & + & CL24/79, E2786, E3089 \\
\hline $\begin{array}{l}\text { L-Pyroglutamyl-2-naphthylamide } \\
\text { hydrolase production }\end{array}$ & 25 & + & CL25/79, A561, B2623 \\
\hline $\begin{array}{l}\alpha \text {-L-Glutamyl-2-naphthylamide hy- } \\
\text { drolase production }{ }^{a}\end{array}$ & 24 & + & CL201/75, CL25/79, A7543, B3159 \\
\hline $\begin{array}{l}\text { L-Threonyl-2-naphthylamide hy- } \\
\text { drolase production }{ }^{a}\end{array}$ & 24 & + & CL25/79, B3159, B9042, D8864 \\
\hline Lactosidase production ${ }^{\alpha}$ & -21 & + & $\begin{array}{l}\text { CL406/79, A7810, A8895, B3159, B3392, } \\
\text { B5147, E2786 }\end{array}$ \\
\hline Deoxyribonuclease production & 17 & + & $\begin{array}{l}\text { CL201/75, CL406/79, 8354, A1327, } \\
\text { A7543, B5147, B5367, D3833, E2786, } \\
\text { E3089, E3540 }\end{array}$ \\
\hline $\begin{array}{l}\text { L-Valyl-2-naphthylamide hydrolase } \\
\text { production }^{a, b}\end{array}$ & 15 & + & $\begin{array}{l}\text { CL201/75, CL24/79, CL25/79, CL26/ } \\
\text { 79, CL406/79, A7810, A8895, B3159, } \\
\text { B3392, B9042, D8510, D8864, E3540 }\end{array}$ \\
\hline$\beta$-D-Galactosidase production ${ }^{a, b}$ & 15 & + & $\begin{array}{l}\text { CL201/75, CL23/79, CL24/79, CL25/ } \\
\text { 79, CL26/79, 8354, A1327, A7317, } \\
\text { A7810, B3392, B5367, B5759, B9042 }\end{array}$ \\
\hline $\begin{array}{l}\text { Acid from ammonium salt-rham- } \\
\text { nose }\end{array}$ & 13 & + & $\begin{array}{l}\text { CL201/75, CL23/79, CL25/79, 8354, } \\
\text { A561, A1327, A7317, A7543, B5367, } \\
\text { B5533, B5759, D8510, E3540 }\end{array}$ \\
\hline$\beta$-D-Glucosidase production ${ }^{a, b}$ & 10 & - & $\begin{array}{l}\text { 8354, A1327, A7317, A7371, A7543, } \\
\text { A7810, B5759, B9042, D3833, E2786 }\end{array}$ \\
\hline$\alpha-\mathrm{L}$-Arabinosidase production ${ }^{a}$ & 8 & - & $\begin{array}{l}\text { CL24/79, A561, A7371, A7543, A8895, } \\
\text { B3392, E2786, E3540 }\end{array}$ \\
\hline $\begin{array}{l}\text { L-Tyrosyl-2-naphthylamide hydro- } \\
\text { lase production }\end{array}$ & 8 & - & $\begin{array}{r}\text { CL201/75, CL23/79, A1327, A8895, } \\
\text { B3159, B9042, D8510, D8864 }\end{array}$ \\
\hline Gelatin hydrolysis $^{c}$ & 4 & - & A561, B5759, B9042, D8510 \\
\hline$\beta$-D-Xylosidase production ${ }^{a}$ & 4 & - & A561, A7371, A7543, E3089 \\
\hline Acid from peptone-water-glucose & 3 & - & CL201/75, CL406/79, A7543 \\
\hline $\mathrm{KCN}$ tolerance & 1 & - & D8510 \\
\hline Opalescence on lecithovitellin agar & 1 & - & $\mathbf{B 5 7 5 9}$ \\
\hline Phosphatase production $^{\alpha}$ & 1 & - & CL24/79 \\
\hline $\begin{array}{l}\text { Pigment production on tyrosine } \\
\text { agar }\end{array}$ & 1 & - & E3540 \\
\hline$\alpha$-D-Galactosidase production ${ }^{a, b}$ & 1 & - & B3159 \\
\hline$\alpha$-L-Fucosidase production ${ }^{a, b}$ & 1 & - & B3159 \\
\hline$\alpha-\mathrm{D}-\mathrm{Xylosidase}$ production ${ }^{a}$ & 1 & - & CL23/79 \\
\hline $\begin{array}{l}\text { L-Isoleucyl-2-naphthylamide hydro- } \\
\text { lase production }{ }^{a}\end{array}$ & 1 & - & 8354 \\
\hline
\end{tabular}

${ }^{a}$ Tested by using various API ZYM galleries.

${ }^{b}$ Enzyme test included in the standard API ZYM gallery.

${ }^{c}$ By plate method; all strains tested failed to liquefy a nutrient gelatin stab.

stained rods, $1.0 \mu \mathrm{m}$ in length, with parallel sides and rounded ends. The colonies on nutrient agar after $48 \mathrm{~h}$ were circular, $1 \mathrm{~mm}$ in diameter, low convex, smooth, and opaque (translucent at 24 h). A pale yellow pigment was produced which did not diffuse in nutrient agar or fluoresce on
King medium B; pigment was clearly yellow at $48 \mathrm{~h}$. Only one strain (E3540) produced a dark brown pigment on tyrosine agar. The colonies were butyrous in consistency and were easily emulsified in distilled water to give uniform suspensions. Colonies of strains A1327, A8895, and 
E3089 appeared rough when first subcultured on nutrient agar, but the colonies appeared smooth on further subculture. The strains grew opti- mally at $30^{\circ} \mathrm{C}$, and all biochemical tests, unless specified otherwise, were carried out at this temperature. The strains grew at room temperature

\section{Percentage Similarity}

\begin{tabular}{ccccc}
0.80 & 0.85 & 0.90 & 0.95 & 1.00 \\
1 & 1 & 1 & 1 & 1 \\
\hline
\end{tabular}

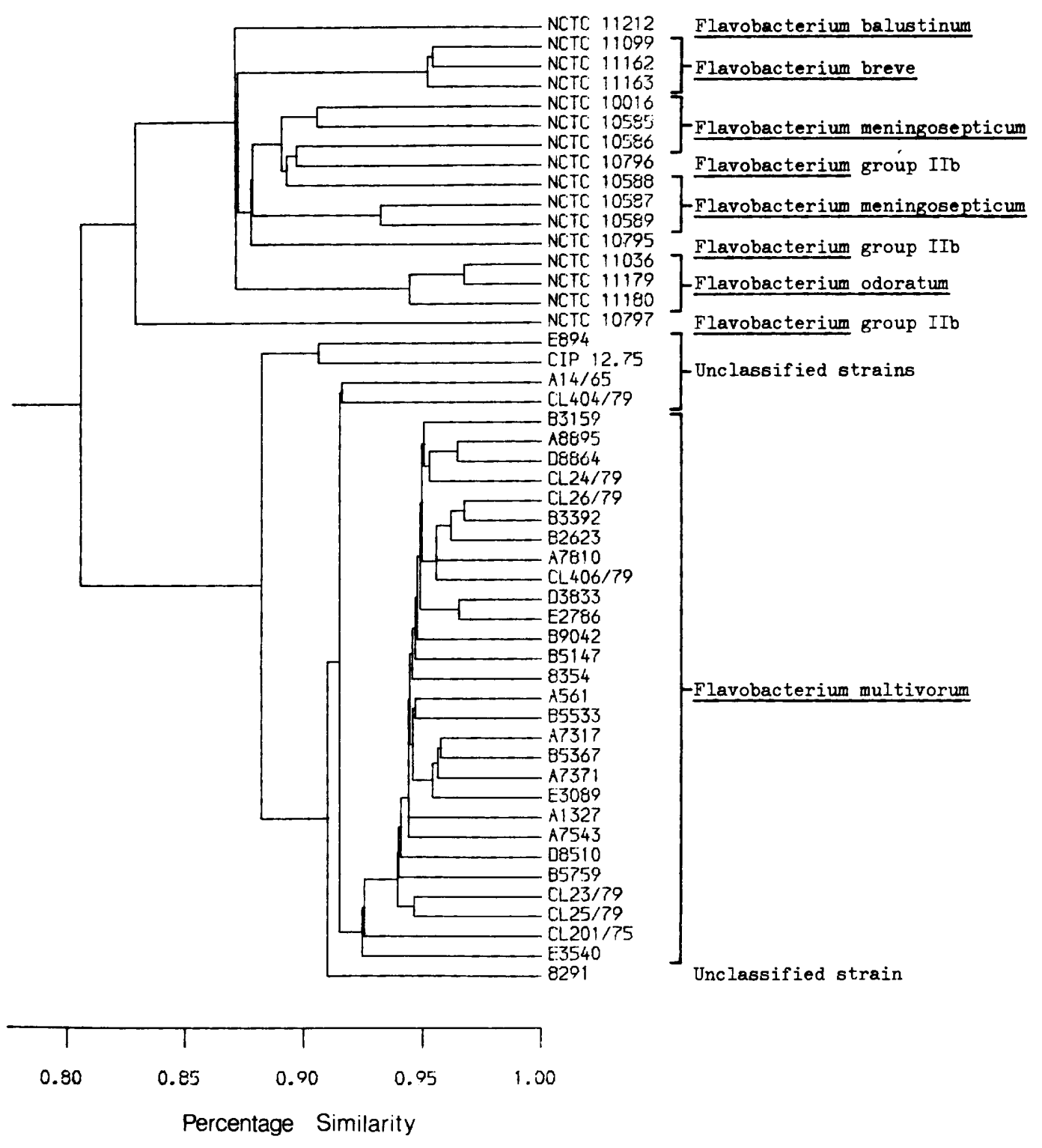

Fig. 1. Dendrogram based on single-linkage cluster analysis. Percent similarity was calculated with the general similarity coefficient of Gower $\left(S_{\mathrm{G}}\right)$, negative matches included. 


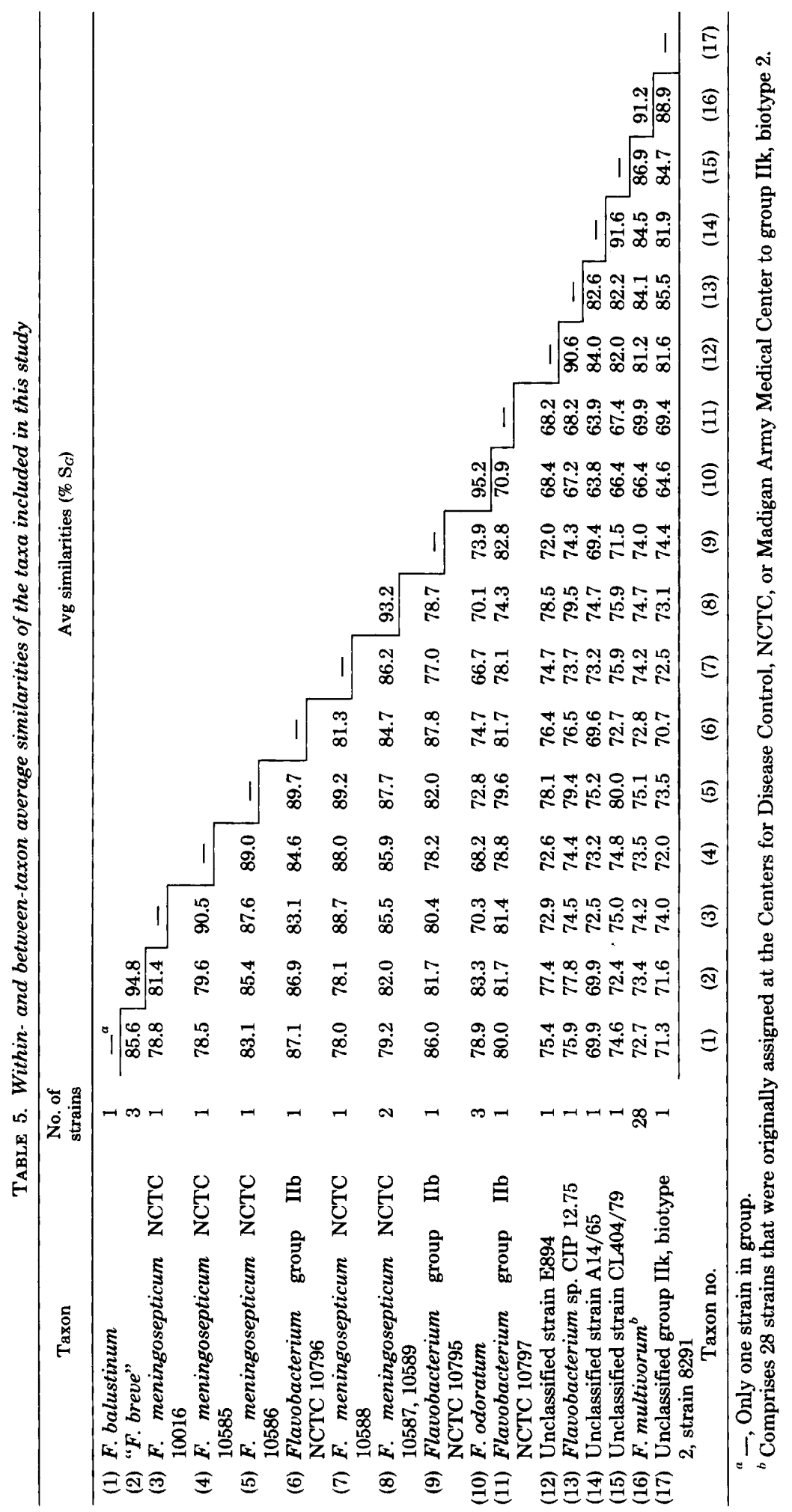


and at $37^{\circ} \mathrm{C}$, but not at 5 or $42^{\circ} \mathrm{C}$. Hemolysis was not obtained from aerobic growth on $5 \%$ (vol/vol) horse blood agar.

The biochemical characteristics of the strains are listed in Tables 2 through 4 . A total of 97 characteristics were common to all strains (either all positive [Table 2] or all negative [Table 3]), and there were 30 characteristics in which one or more of the strains differed (Table 4). The tests with the largest number of strain differences were acid from rhamnose in ammonium salt-sugar medium and production of $L$ valyl-2-naphthylamide hydrolase and $\beta$-D-galactosidase (tested by the API ZYM System) (Table 4). It should be noted that all strains of $F$. multivorum produced phosphatase and $\beta$-Dgalactosidase by conventional methods (Table 2 ), whereas by the API ZYM method, only 1 strain produced phosphatase and 15 strains produced $\beta$-D-galactosidase (Table 4). These discrepancies between the test methods were attributed to the fact that in the API ZYM system, only grades of color change in the range 3 to 5 were treated as positive. However, in the phosphatase production (API ZYM) test, 23 of 27 strains scored as negative produced a slight color change (grades 1 and 2), and in the $\beta$-D-galactosidase production (API ZYM) test, 11 of 13 strains scored as negative produced a color change (grades 1 and 2). The susceptibilities of selected strains to antimicrobial agents are listed in Table 6. The 12 strains tested were resistant to therapeutic levels of streptomycin, kanamycin, gentamicin, tobramycin, amikacin, ampicillin, carbenicillin, cephaloridine, erythromycin, polymyxin $B$, and nalidixic acid and moderately susceptible to sulfamethoxazole, co-trimoxazole, trimethoprim, chloramphenicol, and tetracycline.

DNA base composition. Table 7 lists the base compositions of 11 phenotypically representative strains of $F$. multivorum. The values ranged from 38.6 to $40.1 \mathrm{~mol} \% \mathrm{G}+\mathrm{C}$, with a mean of $39.6 \mathrm{~mol} \%$ and a standard deviation of \pm 0.5 mol\%.

Strains of uncertain taxonomic position. Several strains (taxon numbers 12, 13, 14, 15, and 17 in Table 5) had similarities to $F$. multivorum (Table 5 and Fig. 1) but were excluded from the species because they did not form a cluster with it at the $92.0 \%$ similarity level on the dendrogram derived from single-linkage cluster analysis. Strain 8291 was hitherto regarded as belonging to group IIk, biotype 2 . On the dendrogram derived from unweighted pairgroup average linkage, these strains, except for strain 8291, were again excluded from the $F$. multivorum cluster. The main characteristics that distinguish these unclassified strains from
F. multivorum are given in Table 8 . The $\mathrm{G}+\mathrm{C}$ contents determined on three of the five strains were slightly higher, in the range 40.7 to 43.4 mol\% (Table 7), than those of $F$. multivorum. These strains may provide the bases of future taxa.

\section{DISCUSSION}

The results of the cluster analysis and the within-group similarities presented above show that the 28 strains of yellow-pigmented bacteria, for which the name Flavobacterium multivorum (mul.ti.vo'rum. L. adj. multus many; L. trans.v. vorare to swallow; M.L. adj. multivorus intended to mean "produces acid from many carbohydrates") is here proposed, constitute a homogeneous and distinctive taxon. These findings were corroborated by similarities among strains both with respect to the $\mathrm{G}+\mathrm{C}$ contents of their DNAs and their patterns of susceptibilities to antimicrobial agents.

The 28 strains for which we propose the name F. multivorum conform to the definition of Flavobacterium as emended by Holmes and Owen (9), although they were not actively proteolytic, unlike most members of the genus, and did not produce indole, even in small quantities. We exclude these strains from Pseudomonas on the basis of the $\mathrm{G}+\mathrm{C}$ contents of their DNAs. Tatum et al. (25) found 2 of their 40 group IIk, biotype 2 , strains to be motile, but they cautioned that the results of tests for motility in semisolid medium may be equivocal. Consequently group IIk, biotype 2, was described as monotrichous. However, the group IIk, biotype 2, strains described here and those of Yabuuchi et al. [Abstr. Annu. Meet. Am. Soc. Microbiol. 1979, C(H)32, p. 351], were nonmotile. The presence of flagella has been reported on cells of the type strain of Flavobacterium aquatile and of the type strain of $F$. meningosepticum (27). Weeks (28) described structures on $F$. aquatile strain F36 that did not appear to be true flagella and which he considered similar to pseudoflagella. These pseudoflagella were seen on cells after silver impregnation and on chromium-shadowed cells under the electron microscope, but they were not seen on cells stained by Leifson's procedure. In the case of $F$. meningosepticum, the results of Webster and Hugh (27) represent the first reported observation of motility in this species, and we believe further confirmation by electron microscopy of the nature of the structures observed is required.

The numerical taxonomic analysis showed that $F$. multivorum was quite distinct from the other main taxa that would be included in Flavobacterium: F. balustinum, "F. breve," F. meningosepticum, F. odoratum (9), and Flavobac- 


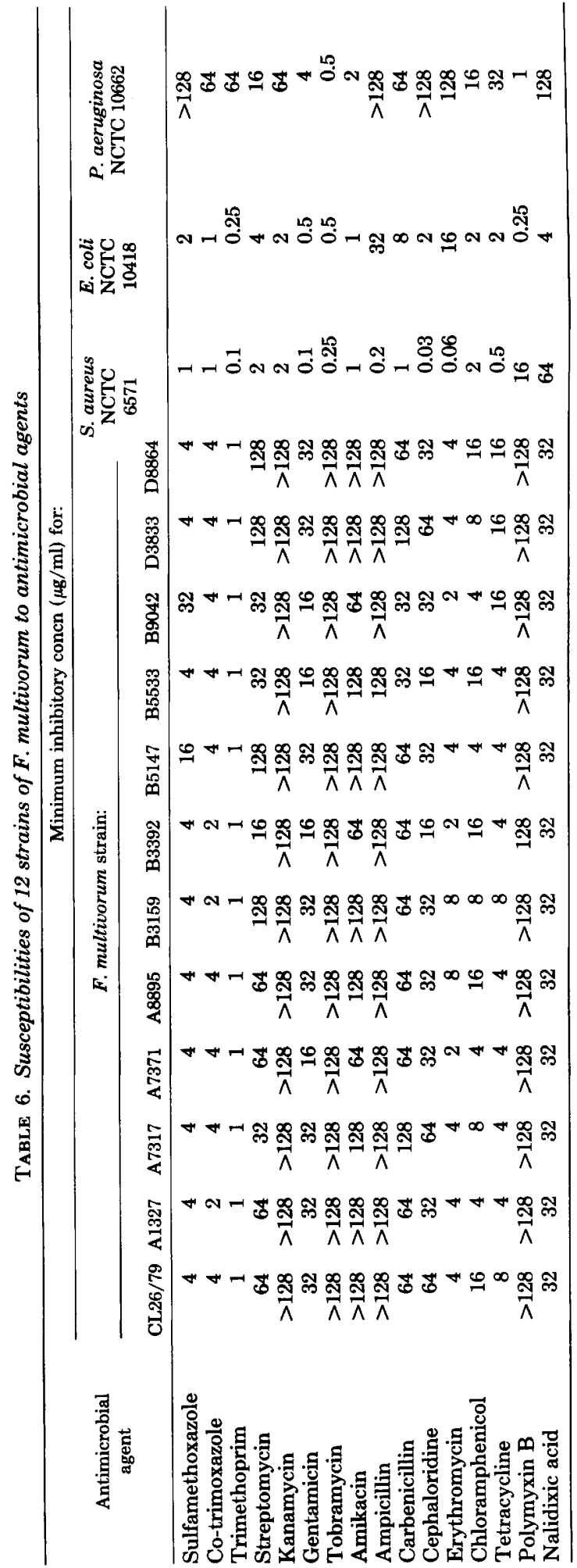


TABLE 7. DNA base compositions of 11 strains of $F$. multivorum and 3 unclassified strains resembling $F$. multivorum

\begin{tabular}{|c|c|c|c|c|}
\hline Strain & Designation & Buffer $^{a}$ & $T_{m} \pm \mathrm{SD}\left({ }^{\circ} \mathrm{C}\right)^{b}$ & $\begin{array}{c}\mathrm{G}+\mathrm{C} \text { content } \\
(\mathrm{mol} \%)^{c}\end{array}$ \\
\hline A561 & F. multivorum & $1 / 3 \mathrm{SSC}$ & $78.4 \pm 0.00$ & 38.6 \\
\hline B5367 & F. multivorum & $1 / 3 \mathrm{SSC}$ & $78.7 \pm 0.10$ & 39.2 \\
\hline E3540 & F. multivorum & $1 / 3 \mathrm{SSC}$ & $78.7 \pm 0.00$ & 39.2 \\
\hline B5533 & F. multivorum & $1 / 3 \mathrm{SSC}$ & $78.75 \pm 0.05$ & 39.3 \\
\hline CL23/79 & F. multivorum & $1 / 3 \mathrm{SSC}$ & $78.85 \pm 0.05$ & 39.6 \\
\hline CL406/79 & F. multivorum & $1 / 3 \mathrm{SSC}$ & $78.85 \pm 0.25$ & 39.6 \\
\hline A7317 & F. multivorum & $1 / 3 \mathrm{SSC}$ & $78.9 \pm 0.10$ & 39.7 \\
\hline B2623 & F. multivorum & $1 / 3 \mathrm{SSC}$ & $78.95 \pm 0.15$ & 39.8 \\
\hline A7810 & F. multivorum & $1 / 3 \mathrm{SSC}$ & $79.05 \pm 0.15$ & 40.0 \\
\hline A8895 & F. multivorum & $1 / 10 \mathrm{SSC}$ & $70.2 \pm 0.05^{d}$ & 40.1 \\
\hline B3159 & F. multivorum & $1 / 10 \mathrm{SSC}$ & $70.2 \pm 0.05^{d}$ & 40.1 \\
\hline E894 & Unclassified strain & SSC & $86.3 \pm 0.20$ & $40.7^{d}$ \\
\hline $\mathrm{A} 14 / 65$ & Unclassified strain & SSC & $86.5 \pm 0.05$ & $41.1^{d}$ \\
\hline 8291 & Unclassified strain & $1 / 3 \mathrm{SSC}$ & $80.55 \pm 0.05$ & 43.4 \\
\hline
\end{tabular}

${ }^{a}$ Compositions of the buffers used: $1 / 3 \mathrm{SSC}, 0.05 \mathrm{M} \mathrm{NaCl}-0.005 \mathrm{M}$ trisodium citrate; $1 / 10 \mathrm{SSC}, 0.015 \mathrm{M}$ $\mathrm{NaCl}-0.0015 \mathrm{M}$ trisodium citrate; SSC, $0.15 \mathrm{M} \mathrm{NaCl}-0.015 \mathrm{M}$ trisodium citrate.

${ }^{b}$ The thermal denaturation temperature $\left(T_{m}\right)$ is the mean of two or three determinations and the standard deviation (SD).

' The equations used to calculate moles percent $\mathrm{G}+\mathrm{C}$ were as follows: $1 / 3 \mathrm{SSC}$, moles percent $\mathrm{G}+\mathrm{C}=52.0$ $+\left[2.24\left(T_{m}-84.4\right)\right] ; 1 / 10 \mathrm{SSC}$, moles percent $\mathrm{G}+\mathrm{C}=52.0+\left[2.08\left(T_{m}-75.9\right)\right]$. The mean value for the 11 strains designated $F$. multivorum was $39.6 \pm 0.5 \mathrm{~mol} \% \mathrm{G}+\mathrm{C}$.

${ }^{d}$ This value was published previously (10).

TABLE 8. Characteristics for differentiation of five unclassified strains phenotypically resembling $F$. multivorum

\begin{tabular}{|c|c|c|c|c|c|c|}
\hline \multirow{2}{*}{ Test } & \multirow{2}{*}{$\underset{\text { multivorum }}{\text { F. }}$} & \multicolumn{5}{|c|}{ Strain no. } \\
\hline & & 8291 & E894 & CIP 12.75 & $\mathrm{~A} 14 / 65$ & CL404/79 \\
\hline Acid from ASS $^{b}$-adonitol & - & + & + & + & - & - \\
\hline Acid from ASS-arabinose & + & + & - & + & - & - \\
\hline Acid from ASS-ethanol & - & - & - & - & + & + \\
\hline Acid from ASS-mannitol & - & - & - & - & + & + \\
\hline Acid from ASS-xylose & + & + & - & + & + & + \\
\hline Growth at $42^{\circ} \mathrm{C}$ & - & + & - & - & - & - \\
\hline Nitrate reduction & - & + & - & + & - & - \\
\hline Production of yellow pigment & + & + & + & + & - & - \\
\hline \multicolumn{7}{|l|}{$\begin{array}{l}\text { Production of the following en- } \\
\text { zymes }{ }^{c} \text { : }\end{array}$} \\
\hline $\begin{array}{l}\text { drolase } \\
N \text {-Benzoyl-DL-arginyl-2- }\end{array}$ & - & - & - & + & - & - \\
\hline naphthylamide hydrolase & - & - & + & + & + & + \\
\hline Arylsulfatase & - & - & + & - & + & - \\
\hline \multirow{3}{*}{\multicolumn{7}{|c|}{$\begin{array}{l}\text { L-Phenylalanyl-2-naphthyla- } \\
\text { mide hydrolase } \\
N \text {-Carbobenzoxy-L-arginyl-4- } \\
\text { methoxyl-2-naphthylamide }\end{array}$}} \\
\hline & & & & & & \\
\hline & & & & & & \\
\hline hydrolase & - & - & + & + & + & - \\
\hline
\end{tabular}

${ }^{a}$ Based on a study of 28 strains. +, All strains tested positive; -, all strains tested negative.

${ }^{b}$ ASS, Ammonium salt-sugar medium.

c Tested by using various API ZYM galleries.

terium sp. group IIb. Characteristics useful in the practical identification of $F$. multivorum and in its differentiation from the above-mentioned taxa are recorded in Table 9. P. paucimobilis is also included in Table 9 because of its apparent similarities to $F$. multivorum.

The strains of $\boldsymbol{F}$. multivorum described here were isolated from various clinical specimens, and one strain (CL406/79) was reported to be the cause of a spontaneous bacterial peritonitis (4). There is no other evidence of strains incriminated in infections in humans, but their resistance to a wide range of antimicrobial agents indicates that any infections due to this species 
TABLE 9. Characteristics for practical identification and differentiation of Test result ${ }^{\prime \prime}$

\begin{tabular}{|c|c|c|c|c|c|c|c|c|c|c|c|c|c|}
\hline \multirow{3}{*}{ Taxon } & \multirow[b]{3}{*}{$\begin{array}{l}\text { No. of } \\
\text { strains }\end{array}$} & \multicolumn{12}{|c|}{ Test result ${ }^{a}$} \\
\hline & & \multicolumn{12}{|c|}{ Acid from ammonium salt medium plus: } \\
\hline & & $\begin{array}{l}\text { Glu- } \\
\text { cose }\end{array}$ & $\begin{array}{c}\text { Arabi- } \\
\text { nose }\end{array}$ & $\begin{array}{l}\text { Cello- } \\
\text { biose }\end{array}$ & $\begin{array}{l}\text { Etha- } \\
\text { nol }\end{array}$ & $\begin{array}{l}\text { Glyc- } \\
\text { erol }\end{array}$ & $\begin{array}{l}\text { Lac- } \\
\text { tose }\end{array}$ & $\begin{array}{c}\text { Mal- } \\
\text { tose }\end{array}$ & $\begin{array}{l}\text { Raffi- } \\
\text { nose }\end{array}$ & $\begin{array}{c}\text { Sali- } \\
\text { cin }\end{array}$ & $\begin{array}{l}\text { Su- } \\
\text { crose }\end{array}$ & $\begin{array}{c}\text { Tre- } \\
\text { halose }\end{array}$ & $\begin{array}{l}\mathrm{Xy}- \\
\text { lose }\end{array}$ \\
\hline F. multivorum & 28 & + & + & + & - & $27 / 28$ & + & + & + & + & + & + & + \\
\hline F. balustinum & 1 & + & - & - & + & - & - & - & - & - & - & - & - \\
\hline "F. breve" & 7 & $6 / 7$ & - & - & - & - & - & $6 / 7$ & - & - & - & - & - \\
\hline $\begin{array}{l}F . \text { meningosep- } \\
\text { ticum }\end{array}$ & 9 & $8 / 9$ & - & $1 / 9$ & $4 / 9$ & $8 / 9$ & $6 / 9$ & + & - & - & - & + & $1 / 9$ \\
\hline F. odoratum & 28 & - & - & - & - & - & - & - & - & - & - & - & - \\
\hline $\begin{array}{l}\text { Flavobacterium } \\
\text { group IIb }\end{array}$ & 4 & + & $2 / 4$ & - & - & $3 / 4$ & - & + & - & - & - & + & $1 / 4$ \\
\hline P. paucimobilis & 29 & + & + & + & $26 / 29$ & $6 / 29$ & + & + & $28 / 29$ & $26 / 29$ & + & + & + \\
\hline
\end{tabular}

${ }^{a}+$, All strains positive; - , all strains negative; fractions indicate numbers of strains positive over numbers of strains tested. The phenotypic results for $F$. multivorum and for $F$. balustinum were from this study, and the phenotypic results for the other taxa were derived from previously published work in NCTC: " $F$. breve" (12), $F$. meningosepticum $(10,12), F$. odoratum (13), Flavobacterium group IIb $(10,12)$, and $P$. paucimobilis (10).

could prove difficult to treat. Resistance to antimicrobial agents is a characteristic of several other Flavobacterium and allied taxa, notably " $F$. breve" (12), F. meningosepticum $(1,14), F$. odoratum $(11,13)$, and Flavobacterium sp. group IIb (26).

Description of the type strain. The characteristics of the type strain, B5533 (= NCTC 11343), also listed in Tables 2 through 4 , are as follows.

Gram-negative, nonsporeforming rods, $1.0 \mu \mathrm{m}$ in length, of regular shape with rounded ends. Cells occurring singly or in pairs. Nonmotile in hanging-drop preparations after overnight growth in nutrient broth incubated at either $37^{\circ} \mathrm{C}$ or room temperature.

Circular, low convex, smooth, and opaque colonies developing on nutrient agar after 2 days; colonies nonhemolytic on $5 \%$ (vol/vol) horse blood agar; on nutrient agar, production of a yellow pigment which is not fluorescent. No production of brown pigment on tyrosine agar.

Aerobic; no growth under anaerobic conditions in an atmosphere of pure hydrogen, but possible growth in the presence of $7 \%(\mathrm{vol} / \mathrm{vol})$ $\mathrm{CO}_{2}$.

Growth at $37^{\circ} \mathrm{C}$ but not at 5 or $42^{\circ} \mathrm{C}$. Optimum temperature: about $30^{\circ} \mathrm{C}$.

Production of catalase, cytochrome oxidase, and deoxyribonuclease.

Production of urease.

No toleration of $\mathrm{KCN}$ at a concentration of $0.0075 \%(\mathrm{wt} / \mathrm{vol})$. Hydrolysis of Tween 20 and Tween 80.

No production of opalescence on lecithovitellin agar.

No reduction of nitrate to nitrite; no reduction of nitrite.
No production of indole and hydrogen sulfide. Growth on $\beta$-hydroxybutyrate (without production of lipid inclusion granules) and on MacConkey agar, but not on cetrimide agar.

No digestion of casein and no hydrolysis of gelatin.

Hydrolysis of esculin and tributyrin, but not starch or tyrosine.

No utilization of citrate and malonate.

No oxidation of gluconate.

No production of arginine deimidase, arginine deiminase, lysine decarboxylase, and ornithine decarboxylase.

No production of 3-ketolactose.

No reduction of selenite and and no deamination of phenylalanine.

Production of phosphatase and $\beta$-D-galactosidase (when tested, respectively, by method 1 of Cowan [2] and the method given by Holmes et al. [8]).

Production of acid in ammonium salt medium under aerobic conditions from glucose, arabinose, cellobiose, glycerol, fructose, lactose, maltose, raffinose, rhamnose, salicin, sucrose, trehalose, and xylose.

Production of acid from $10 \%$ (wt/vol) glucose and $10 \%(\mathrm{wt} / \mathrm{vol})$ lactose.

No production of acid in ammonium salt medium under aerobic conditions from adonitol, dulcitol, ethanol, inositol, mannitol, or sorbitol.

No production of acid or gas from glucose in peptone-water medium; production of acid in only the open tube of Hugh and Leifson oxidation-fermentation glucose medium.

Production of the following enzymes (using various API ZYM galleries): alkaline phosphatase, esterase-lipase (C-8), L-leucyl-2-naphthylamide hydrolase, L-valyl-2-naphthylamide 
F. multivorum from other Flavobacterium taxa and from $P$. paucimobilis

\begin{tabular}{ccccccccccc}
\hline \multicolumn{10}{c}{ Test result } & \\
\hline $\begin{array}{c}\text { Casein } \\
\text { diges- } \\
\text { tion }\end{array}$ & $\begin{array}{c}\text { Esculin } \\
\text { hydrol- } \\
\text { ysis }\end{array}$ & $\begin{array}{c}\text { Gelatin } \\
\text { hydroly- } \\
\text { sis (plate } \\
\text { method) }\end{array}$ & $\begin{array}{c}\text { Growth on } \\
\text { MacConkey } \\
\text { agar }\end{array}$ & $\begin{array}{c}\text { Motility } \\
\text { at room } \\
\text { tempera- } \\
\text { ture }\end{array}$ & $\begin{array}{c}\text { Nitrite } \\
\text { reduc- } \\
\text { tion }\end{array}$ & $\begin{array}{c}\text { Poly- } \beta- \\
\text { hydroxy- } \\
\text { butyrate } \\
\text { inclusion } \\
\text { granules }\end{array}$ & $\begin{array}{c}\text { Starch } \\
\text { hydrol- } \\
\text { ysis }\end{array}$ & $\begin{array}{c}\text { Urease } \\
\text { produc- } \\
\text { tion }\end{array}$ & $\begin{array}{c}\beta \text {-D-Ga- } \\
\text { lactosi- } \\
\text { dase pro- } \\
\text { duction }\end{array}$ & $\begin{array}{c}\text { Mondard devia- } \\
\text { tion (no. of strains } \\
\text { tested) }\end{array}$ \\
\hline- & + & $4 / 28$ & + & - & - & - & - & $27 / 28$ & + & $39.6 \pm 0.5(11)$ \\
+ & + & + & + & - & - & - & - & - & - & 33.1 \\
+ & - & + & + & - & - & - & - & - & - & $32.4 \pm 0.6(10)$ \\
+ & + & + & + & - & $1 / 9$ & - & - & - & + & $37.0 \pm 0.5(8)$ \\
+ & - & + & + & - & + & - & - & + & - & $31.4-36.1(10)$ \\
+ & + & + & + & - & $1 / 4$ & - & + & - & $1 / 4$ & $37.5 \pm 1.4(9)$ \\
- & + & $3 / 29$ & - & $22 / 29$ & - & $25 / 29$ & $18 / 29$ & - & + & $65.3 \pm 1.0(12)$ \\
\hline
\end{tabular}

${ }^{b}$ Data for $F$. multivorum were obtained in this study, and those for the other taxa were derived from previously published work: $F$. meningosepticum and Flavobacterium group IIb (22), $F$. odoratum (21), $P$. paucimobilis (10), and " $F$. breve" and $F$. balustinum (R. J. Owen, unpublished data).

hydrolase, acid phosphatase, phosphoamidase, $\beta$-D-galactosidase, $\alpha$-D-glucosidase, $N$-acetyl- $\beta$ $D$-glucosaminidase, lactosidase, $\beta$-D-cellobiosidase, L-pyroglutamyl-2-naphthylamide hydrolase, L-phenylalanyl-2-naphthylamide hydrolase, L-lysyl-2-naphthylamide hydrolase, L-histidyl-2-naphthylamide hydrolase, glycyl-2-naphthylamide hydrolase, $\alpha$-L-aspartyl-2-naphthylamide hydrolase, L-arginyl-2-naphthylamide hydrolase, L-alanyl-2-naphthylamide hydrolase, $\alpha$ L-glutamyl-2-naphthylamide hydrolase, $S$-benzyl-L-cysteyl-2-naphthylamide hydrolase, L-methionyl-2-naphthylamide hydrolase, L-glycylglycyl-2-naphthylamide hydrolase, glycyl-Lphenylalanyl-2-naphthylamide hydrolase, glycyl-L-prolyl-2-naphthylamide hydrolase, L-leucyl-glycyl-2-naphthylamide hydrolase, L-serylL-tyrosyl-2-naphthylamide hydrolase, L-glutaminyl-2-naphthylamide hydrolase, $\alpha$-L-glutamyl2-naphthylamide hydrolase, L-ornithyl-2-naphthylamide hydrolase, L-seryl-2-naphthylamide hydrolase, L-threonyl-2-naphthylamide hydrolase, L-tryptophyl-2-naphthylamide hydrolase, $N$-carbobenzoxy-glycyl-glycyl-L-arginyl-2-naphthylamide hydrolase.

No production of the following enzymes (using various API ZYM galleries): esterase (C-4), lipase (C-14), L-cystyl-2-naphthylamide hydrolase, $N$-benzoyl-DL-arginyl-2-naphthylamide hydrolase, $N$-glutaryl-L-phenylalanyl-2-naphthylamide hydrolase, $\alpha$-D-galactosidase, $\beta$-D-glucuronidase, $\beta$-D-glucosidase, $\alpha$-D-mannosidase, $\alpha$ $\mathrm{L}$-fucosidase, $\beta$-D-xylosidase, phosphatase, $\alpha$-Dxylosidase, $\beta$-D-fucosidase, $\beta$-L-fucosidase, $N$ acetyl- $\alpha$-D-glucosaminidase, arylsulfatase, $\alpha$-Larabinosidase, L-tyrosyl-2-naphthylamide hydrolase, L-hydroxyprolyl-2-naphthylamide hydrolase, $\quad N$-benzoyl-L-leucyl-2-naphthylamide hydrolase, $\quad N$-carbobenzoxy-L-arginyl-4-meth- oxyl-2-naphthylamide hydrolase, L-isoleucyl-2naphthylamide hydrolase, and L-prolyl-2-naphthylamide hydrolase.

Resistant to streptomycin, kanamycin, gentamicin, tobramycin, amikacin, ampicillin, carbenicillin, cephaloridine, erythromycin, polymyxin $B$, and nalidixic acid and moderately susceptible to sulfamethoxazole, co-trimoxazole, trimethoprim, chloramphenicol, and tetracycline.

$\mathrm{G}+\mathrm{C}$ content of DNA: $39.3 \mathrm{~mol} \%$ (thermal denaturation temperature estimation).

Source: isolated from a spleen.

Two additional strains of $F$. multivorum have been deposited in the National Collection of Type Cultures: NCTC 11033 and NCTC 11034 (group IIk, biotype 2, strains A8895 and B3159, respectively).

\section{ACKNOWLEDGMENTS}

We are extremely grateful to API System for the supply of ZYM galleries and to M. J. Sackin for carrying out the computer analyses. We are grateful to $M$. Scoditti for assistance with the $\mathrm{G}+\mathrm{C}$ estimations and to J. J. S. Snell of the Division of Microbiological Reagents and Quality Control, Neasden Hospital, London, United Kingdom, for the antimicrobial agent susceptibility results. We thank T. R. Oberhofer and W. I. Metzger for supplying us with strains of group IIk, biotype 2, and J. L. Holmes for preparation of data. The staff of the NCTC Computer Identification Laboratory are thanked for their help.

\section{REPRINT REQUESTS}

Address reprint requests to: Dr. R. E. Weaver, Building 5, Room 210, Centers for Disease Control, Atlanta, GA 30333.

\section{LTTERATURE CITED}

1. Altmann, G., and B. Bogokovsky. 1971. In-vitro sensitivity of Flavobacterium meningosepticum to antimicrobial agents. J. Med. Microbiol. 4:296-299.

2. Cowan, S. T. 1974. Cowan and Steel's manual for the identification of medical bacteria, 2nd ed. Cambridge University Press, London. 
3. Dees, S. B., C. W. Moss, R. E. Weaver, and D. Hollis. 1979. Cellular fatty acid composition of Pseudomonas paucimobilis and groups IIk-2, Ve-1, and Ve-2. J. Clin. Microbiol. 10:206-209.

4. Dhawan, V. K., K. R. Rajashekaraiah, W. I. Metzger, T. W. Rice, and C. A. Kallick. 1980 . Spontaneous bacterial peritonitis due to a group IIk-2 strain. J. Clin. Microbiol. 11:492-495.

5. Gower, J. C. 1971. A general coefficient of similarity and some of its properties. Biometrics 27:857-874.

6. Hayes, P. R. 1977. A taxonomic study of flavobacteria and related gram negative yellow pigmented rods. J. Appl. Bacteriol. 43:345-367.

7. Hill, L. R. 1968. The determination of deoxyribonucleic acid base compositions and its application to bacterial taxonomy, p. 177-186. In B. M. Gibbs and D. A. Shapton (ed.), Identification methods for microbiologists, part B. Academic Press, Inc., (London), Ltd., London.

8. Holmes, B., S. P. Lapage, and H. Malnick. 1975. Strains of Pseudomonas putrefaciens from clinical material. J. Clin. Pathol. 28:149-155.

9. Holmes, B., and R. J. Owen. 1979. Proposal that Flavobacterium breve be substituted as the type species of the genus in place of Flavobacterium aquatile and emended description of the genus Flavobacterium: status of the named species of Flavobacterium. Request for an Opinion. Int. J. Syst. Bacteriol, 29:416-426.

10. Holmes, B., R. J. Owen, A. Evans, H. Malnick, and W. R. Willcox. 1977. Pseudomonas paucimobilis, a new species isolated from human clinical specimens, the hospital environment, and other sources. Int. J. Syst. Bacteriol. 27:133-146.

11. Holmes, B., J. J. S. Snell, and S. P. Lapage. 1977. Revised description, from clinical isolates, of Flavobacterium odoratum Stutzer and Kwaschnina 1929, and designation of the neotype strain. Int. J. Syst. Bacteriol. 27:330-336.

12. Holmes, B., J. J. S. Snell, and S. P. Lapage. 1978. Revised description, from clinical strains, of Flavobacterium breve (Lustig) Bergey et al. 1923 and proposal of the neotype strain. Int. J. Syst. Bacteriol. 28:201-208.

13. Holmes, B., J. J. S. Snell, and S. P. Lapage. 1979. Flavobacterium odoratum: a species resistant to a wide range of antimicrobial agents. J. Clin. Pathol. 32:73-77.

14. King, E. O. 1959. Studies on a group of previously unclassified bacteria associated with meningitis in infants. Am. J. Clin. Pathol. 31:241-247.

15. King, E. O., M. K. Ward, and D. E. Raney. 1954. Two simple media for the demonstration of pyocyanin and fluorescin. J. Lab. Clin. Med. 44:301-307.

16. Lapage, S. P., P. H. A. Sneath, E. F. Lessel, V. B. D. Skerman, H. P. R. Seeliger, and W. A. Clark (ed). 1975. International code of nomenclature of bacteria. 1976 Revision. Published for the International Association of Microbiological Societies by the American Society for Microbiology, Washington, D.C.

17. Lapage, S. P., and W. R. Willcox. 1974. A simple method for analysing binary data. J. Gen. Microbiol. 85:376-380.

18. Marmur, J. 1961. A procedure for the isolation of deoxyribonucleic acid from micro-organisms. J. Mol. Biol. 3: 208-218.

19. Marmur, J., and P. Doty. 1962. Determination of the base composition of deoxyribonucleic acid from its thermal denaturation temperature. J. Mol. Biol. 5:109-118.

20. Owen, R. J., L. R. Hill, and S. P. Lapage. 1969. Determination of DNA base compositions from melting profiles in dilute buffers. Biopolymers 7:503-516.

21. Owen, R.J., and B. Holmes.1978. Heterogeneity in the characteristics of deoxyribonucleic acid from Flavobacterium odoratum. FEMS (Fed. Eur. Microbiol. Soc.) Microbiol. Lett. 4:41-46.

22. Owen, R. J., and J. J. S. Snell. 1976. Deoxyribonucleic acid reassociation in the classification of flavobacteria. J. Gen. Microbiol. 93:89-102.

23. Skerman, V. B. D., V. McGowan, and P. H. A. Sneath (ed.). 1980. Approved lists of bacterial names. Int. J. Syst. Bacteriol. 30:225-420.

24. Sneath, P. H. A., and R. R. Sokal. 1973. Numerical taxonomy. W. H. Freeman \& Co., San Francisco.

25. Tatum, H. W., W. H. Ewing, and R. E. Weaver. 1974. Miscellaneous gram-negative bacteria, p. 270-294. In E. H. Lennette, E. H. Spaulding, and J. P. Truant (ed.), Manual of clinical microbiology, 2nd ed. American Society for Microbiology, Washington, D.C.

26. Von Graevenitz, A., and M. Grehn. 1977. Susceptibility studies on Flavobacterium II-b. FEMS (Fed. Eur. Microbiol. Soc.) Microbiol. Lett. 2:289-292.

27. Webster, J. A., and R. Hugh. 1979. Flavobacterium aquatile and Flavobacterium meningosepticum: glucose nonfermenters with similar flagellar morphologies. Int. J. Syst. Bacteriol. 29:333-338.

28. Weeks, O. B. 1955. Flavobacterium aquatile (Frankland and Frankland) Bergey et al., type species of the genus Flavobacterium. J. Bacteriol. 69:649-658. 